\title{
The Potential of Chrysin of Oroxylum indicum L. to Induce Carbonic Anhydrase (CA) to Improve Cattle Fertility
}

\author{
Mohamad Amin ${ }^{1, *}$, Muhammad Najib Fahmi ${ }^{2}$, Muhammad Andi Ali Ridho², \\ Nurul Fitri ${ }^{2}$, Umie Lestari ${ }^{1}$, Dina Maulina ${ }^{3}$, Ihya Fakhrurizal Amin ${ }^{4}$ \\ ${ }^{1}$ Department of Biology, Faculty of Mathematics and Sciences, Universitas Negeri Malang, Jl. Semarang 5, Malang, Indonesia \\ ${ }^{2}$ Postgraduate Program of Biological Education, Universitas Negeri Malang, Jl. Semarang 5, Malang, Indonesia \\ ${ }^{3}$ Biology Education, Faculty of Teacher Training and Education, Universitas Lampung, Jl. Prof. Dr. Soemantri Brojonegoro No. 1, Lampung, Indonesia \\ ${ }^{4}$ Faculty of Medicine, University of Indonesia, Universitas Indonesia, Jl. Salemba Raya No.4, Central Jakarta City, Jakarta, Indonesia
}

Corresponding author*

mohamad.amin.fmipa@um.ac.id

Manuscript received: 11 April, 2020. Revision accepted: 15 April, 2020. Published: 16 April, 2020.

\begin{abstract}
The Artificial Insemination (AI) aims to develop the potential of the cattle reproduction comprehensively. The success of AI results is highly dependent on the level of livestock fertility. Therefore, improv the quality and quantity of semen could be done by hormone induction. However, hormone prices are expensive. This problem could be overcome using alternative way with the natural compound containing chrysin which might has the same function. The purpose of the study was analyze the potential of chrysin compound from Bungli plant (Oroxylum indicum) as fertilizer of males through bioinformatics approach. Methods performed through data search by webserver with the following stages: (1) Pubchem, (2) Swiss (3) Target Prediction, (4) Uniprot, (5) Protein Data Bank and (6) docking software using PyRx, PyMOL and Discovery Studio. The results showed that the chrysin compound interact with carbonic anhydrase (CA) expressed from the testes of the cattle, through van der Waals and Pi-Alkyl bonds. Chrysin is effective as CA ligand inducers based on affinity bonds $(-8.4 \mathrm{kcal} / \mathrm{mole})$ and more negatively than flavonol as a control compound with binding affinity $(-6.2 \mathrm{kcal} / \mathrm{mol})$. This suggests that chrysin is an effective compound as a potential drug for improved livestock fertility.
\end{abstract}

Keywords: bioinformatic; carbonic anhydrase; chrysin; fertility. Bungli plant (Oroxylum Indicum L.).

\section{INTRODUCTION}

Indonesia has a wealth of natural resources that can be optimized to support the productivity of livestock, including herbs that it mixed in the form of traditional herbal medicine (Motaleb et al., 2010; Salim \& Munadi, 2017). Herbal plants can be processed into livestock herbs and are useful for increasing the cattle fertility and can reduce the use of hormones (Balittro, 2015; Affandhy et al., 2017). Increasing the productivity of beef cattle through artificial insemination (AI) is one of the achievement programs of beef self-sufficiency (Direktorat Pangan dan Pertanian, 2010). The success of the artificial insemination program (AI) is highly dependent on the fertility of the cattle (Foote et al., 1999). The quality and quantity improvement of semen is conducted through hormones function (Walker et al, 2005; Afriani, et al., 2014). One of the active compounds that play a role to increase the fertility of cattle is chrysin, a herb plant compound found in Bungli plant (Oroxylum Indicum L.).

Oroxylum Indicum L. (Lamiales: Bignoniaceae) is native to India that used as an ingredient in the manufacture of medicines (Deka et al., 2013). This plant is found in primary and secondary forests or in open areas (Djarwaningsih, 1992). The distribution of the plant is covering at Philippines, Indochina, Siam, India and Indonesia (Java, Sumatra, Borneo, Sulawesi, Nusa Tenggara and Maluku). It has many benefits for health, all part of this plant contain useful compounds that can be used for traditional medicine (Deb, et al., 2016). The previous research showed that this plant is not toxic when consumed by human and animal even in high doses (Lawania et al., 2010).

Research about the bungli plant based on in vivo and in vitro tests revealed that bungli has benefit as antimicrobial (Islam, 2010), anti- free radical (Kalaivani et al., 2009), antiulcer (Khandar et al., 2006), genotoxic (Tepsuwan et al., 1992), anti cancer (Roy et al., 2007), antioxidants (Upaganlawar et al., 2007; Tenpe et al., 2009), and many other functions that have yet proven. This plant contains flavonoids and oils almost in all its parts (Sankara et al., 1972). Flavonoids consist of a large group of polyphenolic compounds that have benzo- $\gamma$-piron structures and are ubiquitous in plants. They are synthesized by phenylpropanoid pathways. Available reports tend to show that phenolic secondary metabolites including flavonoids are responsible for 
various pharmacological activities (Mahomoodally et al., 2005; Pandey, 2007).

Chrysin and baicalein are the most commonly found flavonoid compounds in bungli plant (Yan et al., 2011). The leaf part contains baicalein, 6 and 7-glucoronide, chrysin, anthraquinone and aloe-emodin. The bark contains flavones of oroxylin, chrysin, baicalein, and biochanin-A. While at the root of this plant contains chrysin, skutelarin-7-rutinsococic, weak acid, alkaloids, cytosterol, galactose, baicalein, and biochanin-A (Lawania et al., 2010).

Chrysin, in the chemical name called 5.7 dihydroxyflavone, is a natural polyphenol compound found in bungli plant, honey and several other plants (Morissette, et al., 2017). Chrysin is a flavone-derived compound that has biological activity, has various pharmacological effects including anti-inflammatory, anti-cancer, and antioxidant (Manoharan et al., 2012). Chrysin is a compound of the flavonoid group found in honey, propolis, and plant extracts, which is a powerful antioxidant that has been widely studied because of its mechanism of action to prevent the conversion of testosterone hormones into estrogen through inhibition of the CYP19 enzyme (Ommati et al., 2013; Akhlaghi et al., 2014).

The benefits of these compounds are commonly used by bodybuilding athletes as a testosterone enhancer, but also known as antineoplastic (Neuman et al., 2002), anti-inflammatory (Eid et al., 2006; Rengaraj et al., 20015), anti hypertension (Min et al., 2016), antiaging (Mantawy et al., 2014). In addition, it can protect against the effects of oxidative and inflammatory injury (Mantawy, et al., 2014) along with steroidogenic activity (Jana et al., 2008) and antiaromatase (Campbell et al., 1993). Based on these reasoning, chrysin is an attractive candidate to evaluate its effect on reproduction. Several studies using animal models reported that chrysin improved sperm parameters (Jana et al., 2008; Campbell et al., 1993), raising testosterone level, and preventing oxidative damage caused by exposure to toxic chemicals (Dhawan et al., 2002; Ciftci et al., 2012).

CA (carbonic anhydrase) is a zinc metalloenzyme class that catalyzes reversible hydrogen carbon dioxide. CA has many different physiological functions and seven different isozymes have been characterized in mammals (Hewett-Emmett et al., 2000). CA is abundant in spermatozoa (Parkkila et al., 1991) and its presence may be associated with maintenance of adequate intraspermatozoal bicarbonate concentration required to control sperm motility and acrosome reactions (Tajima et al., 1987).

The presence of CA in male reproductive organs was first shown about 50 years ago. Mawson \& Fisher (1952) showed that biochemically approach the homogenate dorsolateral mouse prostate contained a large amount of CA activity. Many researchers then confirm these findings (Fisher et al., 1955; Pincus \& Bialy 1963; Leiter 1964; McIntosh 1969). Biochemical studies have also shown that human and mice seminal vesicles contain the activity of CA (Miyake \& Pincus, 1959; Maren 1967). CA activity in rats' prostate and seminal vesicles was found to be regulated by androgens. The benefits of chrysin compounds in the bangli plants that could increase male fertility by binding to carbonic anhydrase (CA) protein had tested in silico. This study aims to investigated the Chrysin compound from Bungli as a male cattle fertility drug based on in silico screening.

\section{METHODS}

\section{Retrieval of sample}

This research used chrysin as spesific compound from Oroxylum indicum L. The substance is the most abundant compound in Oroxylum indicum L (Manoharan et al., 2012; Morissette, Litim, \& Paolo, 2017) and it has been reported to have antioxidant activity. Therefore, chrysin was selected as a specific sample for analysis. In addition, the compositions of chrysin were obtained from the compounds database of PubChem.

\section{Ligand Preparation}

The chemical structure of 3D and SMILES ligands (chrysin) is taken from Pubchem compound database (https://pubchem.ncbi.nlm.nih.gov/) with ID number: 5281607.

Target Selection Input chrysin's SMILES on Pharmmapper (http://lilab.ecust.edu.cn) to identify potential target candidates using mapping approaches Swiss Target Predictions (http: //www.swisstargetprediction.c/) and chemical structure associations with molecular 3D.

\section{Molecular docking process}

The molecular reverse docking was used to observe the interactions of chrysin with a target protein. It was identified using: collection of 3D natural compounds structure, predictions of target protein, receptor profiling, and clarification of the potential of chrysin compounds based on mode of action using PyRx 0.8 software.

The collection of natural compounds structure from PubChem was used to identify the biological activity from small molecule. The PubChem was confirmed by three databases that are connected with NCBI's information systems, including PubChem substance, PubChem compound, and PubChem BioAssay. Therefore, 3D structure of the chrysin would be obtained.

Predictions of target protein was identified using PharmMapper, Superpred and Swiss Target Prediction software. They were used to identify the bioactive 
molecule in the animal body. It was performed in order to observe the molecular mechanism that is fundamental as phenotype and their site of biological activity.

The next process, receptor profiling process was obtained using two online databases: UniProt and RSCB Protein Data Bank. The 3D structures are required to further analyze the receptor proteins. The last stage was performed using the Vina Wizard feature which is integrated in PyRx 0.8 software. It was minimized to obtain the most suitable conformation before the interaction with the target protein. Information obtained from Pathway analysis was clarified to identify the action mechanism of chrysin compounds towards the target protein concerned. The natural compound and the control inhibitor compounds (inhibitor compounds or target protein activator) were used as a ligand in this step (Maulina, et al., 2018).

\section{Molecular interaction and visualization}

Finally, the molecular interaction and visualization of the docking results were analyzed using PyMOL and LigPlus $^{+}$software. In this stage, a profiling visualization of an interaction between chrysin compounds with the target protein was conducted. All of the bound chrysin and receptor that interact directly can be observed. Therefore, the new chrysin receptor was analyzed for their structure and function mechanisms in the animal body metabolism specificly in the cattle (Maulina, et al., 2018; Amin, et al., 2018).

\section{RESULT AND DISCUSSION}

Reverse docking is a method used to predict the interaction activity between ligand (compound/drug) with receptors (protein/target) (Kharkar et al., 2014). Based on the docking of CA (carbonate anhydrase) PDB ID: 1JD0) with a resolution of $1.95 \AA$, chrysin compound was known as a ligand informing that both have binding affinities $(-8.3 \mathrm{kcal} / \mathrm{mol})$. The results of molecular visualization and molecular interaction using PyMOL software found that Chrysin binds to target the protein (CA) in the same binding site with the control compound (flavonol) via binding for van der Waals, unfavorable Bump and Pi-Alkyl ARG B: 2401, PRO B: 240, HOH: B, 2617, THR B: 233, TYR B: 231, HOH B: 2572 GLU B: 248 SER B: 239 as shown in Figure 1. So it can be suggest that chrysin has the same function as flavonol as ligand CA for male fertility.

Chrysin as a natural favonoid compound, previously used to increase testosterone (Brown, et al., 2001; Dhawan, et al., 2002). Ciftci, et al., (2011) had studied the steroidogenic effects of flavonoid compounds and found that chrysin significantly increases steroidogenesis in Leydig cells primarily by increasing StAR gene expression.

The effects of chrysin compound was confirmed by Ciftci, et al., (2012) reporting where the levels of testicular antioxidant enzymes such as SOD, CAT and GSH-Px coincide with GSH increased significantly after Chrysin administration. The chrysin-treated male albino mice had more sperm count, a much higher fertility rate when mated to proestrous female mice (Dhawan, et al., 2002). Higher sperm count and motility along with lower percentage of sperm abnormality were also noted in their study. In addition to the antioxidant effects, both in vivo and in vitro studies have confirmed the potential of Chrysin to increase testosterone levels and then male sex drive (Jana et al., 2008; Ciftci et al., 2012).

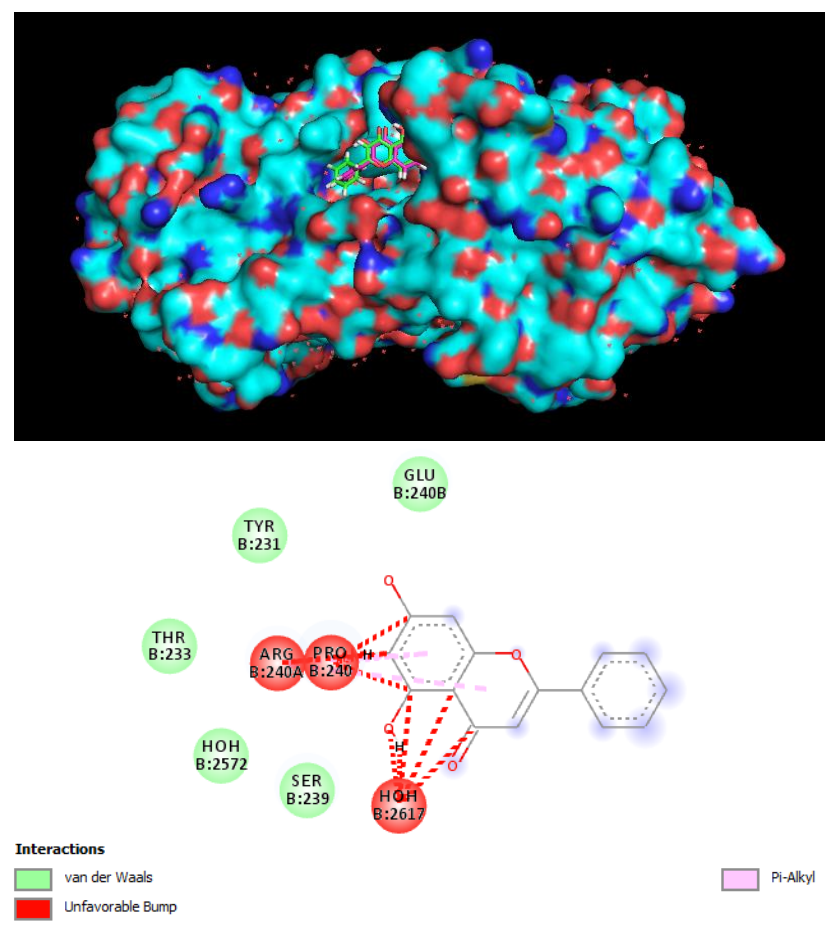

Figure 1. (A) The interaction between target protein (CA) with Chrysin and Flavonol shows that binding to target proteins on the same site. Green (Chrysin), purple (Flavonol), blue (CA); (B) Interaction through van der Waals bond, unfavorable Bump and Pi-Alkyl ARG B: 2401, PRO B: 240, HOH: B, 2617, THR B: 233, TYR B: 231, HOH B: 2572 GLU B: 248 SER B: 239.

The result of target selection using Swiss Target Prediction found that chrysin interacts with CA expressed on the testes for sperm motility and male fertility. This compound is an interesting object of this research for the development of male cattle fertility drug. As a natural compound in Bungli plant, this compound is predicted as an effective substance for male fertility because it is directly linked to CA. In addition, Bungli has active compound of flavonoids as aphrodisiac compounds that can increase sexual arousal (Uddin et al., 2003).

Histochemical studies have demonstrated that CA activity acts and work in the testes, the efferent ducts, epididymis, ductus deferens, seminal vesicles, and prostates in some species (Waldeyer \& Häusler, 1959; 
Cohen et al., 1976; Goyal et al., 1980). In the testes, CA activity has been found in Sertoli and Leydig cells and in interstitial tissues in rats. Capillary endothelial cells and some larger vessels in the testes have been shown that it contains CA activity in many species, including humans (Cohen et al., 1976; Ridderstråle et al., 1985; Ekstedt et al., 1991). Related to this explanation, Mezquita et al., (1999) reported that the expression of $\mathrm{CA}$ conducted during spermatogenesis in rats and the main structure of testicular transcript for CA isolated from adult and human testes. Mezquita, et al. (1999) also suggest that certain transcriptional and posttranscriptional mechanisms regulate the expression of CA during mammalian spermatogenesis.

Harris's et al., (1984) studied the increasing of total semen and seminal volume of plasma per semen collection related to increasing of the CA activity of testicular and ductus deferens. It was showed that the processes occurring in the testes and ductus deferens are closely involved with the total ejaculatory volume. Inhibition of CA activity by acetazolamide showed that it was influenced for decreasing of in semen or seminal plasma volume. This result may be regarded as further evidence of the importance of a bicarbonate buffer system in seminal production. This confirms the linear relationship found in experiments between semen production and CA activity of the testes (Ridderstråle $e t$ al., 1985).

In addition, sperm motility, sperm concentration and serum testosterone levels increased significantly, whereas abnormal sperm levels decreased significantly after chrysin treatment (Zhandi, 2017). In conclusion, it was suggested that treatment with chrysin may affect the reproductive system positively in mice, and may be used for the treatment of male infertility (Ciftci at al., 2011). Findings of the relationship between the volume of semen, spermatozoa or seminal plasma and CA activity in the reproductive system show that $\mathrm{CA}$ is involved in some reproductive functions (Harris and Goto, 1984).

\section{CONCLUSION}

This study proves that chrysin is a potential compound as an inducer of CA based on affinity and intermolecular binding interactions. Chrysin is a potential herb for increasing fertility in male cattle, interacts with CA expressed on the testes for sperm motility and male fertility.

\section{REFERENCES}

Affandhy, L., Ratnawati, D., \& Luthfy, M. 2017. Herbal Combination Effect on the Quality of Semen and Libido in Ongole Cattle Cross-breed. Trad. Med. J. Vol. 22(2), p 84-90 ISSN-p: 1410-5918 ISSN-e: 2406-9086

Afriani, T., Jaswandi., Defrinaldi., \& Satria, Y.E. 2014. Pengaruh Waktu Pemberian Gonadotropin Releasing Hormone (GnRH) terhadap Jumlah Korpus Luteum dan Kecepatan Timbulnya
Berahi pada Sapi Pesisir. Jurnal Peternakan Indonesia. Vol. 16 (3). ISSN 1907-1760

Akhlaghi,A., Ahangari, Y.J., Navidshad, B., Pirsaraei, Z.A., Zhandi, M., \& Deldar, H. 2014. Improvements in semen quality, sperm fatty acids, and reproductive performance in aged Cobb 500 breeder roosters fed diets containing dried ginger rhizomes (Zingiber officinale). Poult Sci, 93:1236e44.

Amin, A., Putra, K.S., Amin, I.F., Earlia, N., Maulina, D., Lukiati, B. \& Lestari, U. 2018. Quercetin: the bioactive compound from Allium cepa $L$. as anti-inflammation based on in silico screening. Journal of Biology, Medicine, \& Natural Product Chemistry, Vol. 7:1. Doi: 10.14421/biomedich.2018.71.27-31

Balittro, B.B.S. 2015. Tanaman Obat Sebagai Bahan Baku Jamu Fertilitas Sapi. Warta Penelitian dan Pengembangan Tanaman Industri. Badan Penelitian dan Pengembangan Pertanian Pusat Penelitian dan Pengembangan Perkebunan. Volume 21, Nomor 3, ISSN 0853 - 8204.

Brown, G.A., Vukovich, M.D., Martini, E.R., Kohut, M.L., Franke, W.D., Jackson, D.A. \& King, D.S. 2001. Effects of androstenedione-herbal supplementation on serum sex hormone concentrations in 30- to 59-year-old men. International Journal for Vitamin and Nutrition Research, 71 293-301.

Campbell, D.R., \& Kurzer, M.S. 1993. Flavonoid inhibition of aromatase enzyme activity in human preadipocytes. $J$ Steroid Biochem Mol Biol, 46:381e8.

Ciftci, O., Ozdemir, I., Aydin, M., \& Beytur, A. 2011. Beneficial effects of chrysin on the reproductive system of adult male rats. Journal Andrologia.

Cohen J.P., Hoffer, A.P. \& Rosen S. 1976. CA localization in the epididymis and testis of the rat: histochemical and biochemical analysis. Biol Reprod, 14: 339-346.

Deb, D., Datta, B. K., Debbarma, J., \& Deb, S. 2016. Ethnomedicinal plants used for herbal medication of jaundice by the indigenous community of Tripura, India. Journal BIODIVERSITAS. Volume 17, Number 1, April 2016. Pages: 256-259. ISSN: 1412-033X. E-ISSN: 2085-4722. DOI: 10.13057/biodiv/d170137.

Deka, D. C., Kumar, V., Prasad, C., Kumar, K., Gogoi, B. J., Singh, L., \& Srivastava, R. B. 2013. Oroxylum indicum- a medicinal plant of North East India: An overview of its nutritional, remedial, and prophylactic properties. Journal of Applied Pharmaceutical Science Vol. 3 (Suppl 1), pp. S104S112, May, 2013. DOI: 10.7324/JAPS.2013.34.S19. ISSN 2231-3354.

Dhawan K, Kumar S \& Sharma A. 2002 Beneficial effects of chrysin and benzoflavone on virility in 2-year-old male rats. Journal of Medicinal Food, 5: 43-48.

Direktorat Pangan dan Pertanian. 2010. Naskah Kebijakan (Policy Paper) Strategi dan Kebijakan dalam Percepatan Pencapaian Swasembada Daging Sapi 2014. Kementerian Perencanaan Pembangunan Nasional/Badan Perencanaan Pembangunan Nasional (BAPPENAS).

Djarwaningsih, T. 1992. Oroxylum indicum (L.) Vent. Dalam: Rifai, M.A., Rugayah, dan E.A. Widjaja (Penyunting). Tiga Puluh Tumbuhan Obat Langka Indonesia. Floribunda, 2:1920.

Edgren, R.A., Knudsen, K.A. \& Jones, R.C .1971. On the role of CA in reproductive processes. J Reprod Fertil, 27:301-302.

Eid Y, Ebeid T, Younis H. 2006. Vitamin E supplementation reduces dexamethasoneinduced oxidative stress in chicken semen. Br Poult Sci, 47:350e6. 
Ekstedt, E., Ridderstråle, Y., Plöen, L \& Rodriguez-Martinez, H. 1991. Histochemical localization of CA in the testis and epididymis of the boar. Acta Anat 141:257-261.

Fisher, M.I., Tikkala, A.O. \& Mawson, C.A. 1955. Zinc, CA and phosphatase in the prostatic glands of the rat. Can J Biochem Physiol, 33:181-190.

Foote, R.H. 1999. Development of reproductive biotechnologies in domestic animals from artificial insemination to cloning: A Perspective. Cloning, 1 (3):133-142.

Goyal, H.O., Ferguson, J.G. \& Hrudka, F. 1980 Histochemical activity of CA in testicular and excurrent ducts of immature, mature intact and androgen-deprived bulls. Biol Reprod 22:991-997.

Harris, G. C., \& Goto, K. 1984. CA activity of the reproductive tract tissues of aged male fowls and its relationship to semen production. Journal Reproduction Fertilization. Vol (70), 2530.

Hewett-Emmet, D. 2000. Evolution and distribution of the CA gene families. In: Chegwidden WR, Carter ND \& Edwards YH (eds) The CAs: New Horizons. Birkhäuser Verlag Basel, Switzerland, p 29-76.

Islam, M.K., Eti, Z.I., \& Chowdhury, J.A. 2010. Phytochemical and Antimicrobial analysis on the extract of Oroxylum indicum (linn.) stembark. Iranian J Pharma \& Therap, 9(1): 25-28.

Jana, K., Yin, X., Schiffer, R.B., Chen, J.J., Pandey, A.K., \& Stocco, D.M. 2008. Chrysin, a natural flavonoid enhances steroidogenesis and steroidogenic acute regulatory protein gene expression in mouse Leydig cells. J Endocrinol,197: $315 \mathrm{e} 23$.

Kalaivani T. \& Mathew L. 2009. Phytochemistry and Free radical scavenging activities of Oroxylum indicum. Environ We Int $J$ Sci Tech.,4: 45-52.

Khandhar M., Shah M., Santani D., \& Jain S. 2006. Antiulcer activity of the root bark of Oroxylum indicum against experimental gastric ulcers. Pharma boil., 44: 363-370.

Kharkar, P., Warrier, S., \& Gaud, R. 2014. Reverse Docking: A Powerful Tool For Drug Repositioning And Drug Rescue. Future Medicinal Chemistry. 6 (3): 333-342.

Kumar V., Chaurasia A.K., Naglot A., Gopalakrishnan R., Gogoi B. J., Singh L., Srivastava R. B., \& Deka D.C. 2011. Antioxidant and antimicrobial activities of stem bark extracts of Oroxylum indicum Vent. (Bignoniaceae) - A medicinal plant of northeastern India. South Asian J Exper Biol., 1(3):152-157.

Lawania R.D., Mishra A., \& Gupta R. 2010. Oroxylum indicum: A Review. Pharmacog J., 2(9): 304-310.

Mahomoodally, M.F., Gurib-Fakim, A, \& Subratty A.H. 2005. Antimicrobial activities and phytochemical profiles of endemic medicinal plants of Mauritius. Pharmaceutical Biology., 43(3):237-242.

Manoharan, S., Murugaraj, M.P., Nagarethinam, P., Ramachandran, S., Sekar, K. \& Shamsul, A.W. 2012. Chemopreventive Potential of Chrysin in 7,12dimethylbenz(a)anthracene Induced Skin Carcinogenesis in Swiss Albino Mice. Int.J.Res.Pharm.Sci.,3(1), 86-96. India: Annamalai University.

Mantawy, E.M., El-Bakly, W.M., Esmat, A., Badr, A.M., \& ElDemerdash, E. 2014. Chrysin alleviates acute doxorubicin cardiotoxicity in rats via suppression of oxidative stress, inflammation and apoptosis. Eur J Pharmacol, 728:107e18.

Maren, T.H. 1967. CA: chemistry, physiology, and inhibition. Physiol Rev 47:595- 781. Hodgen GD, Gomes WR \&
Vandemark NL (1971) A testicular isoenzyme of CA. Biol Reprod 4:224-228.

Maulina, D., Amin, M., Lestari, S.R., \& Aziz, M. 2018. Chrysin as natural biopesticide from Mirabilis jalapa and its interaction with glutamate as an inhibitor in insects immune system. Journal of Biologival Researches, Vol. 23: 2. Doi: 10.23869/bphjbr.23.2.20185.

Mawson, C.A \& Fischer, M.I. 1952. CA and zinc in prostate gland of the rat and rabbit. Arch Biochem Biophys., 36:485486.

McIntosh, J. 1969. CA isoenzymes in the eryhrocytes and dorsolateral prostate of the rat. Biochem J, 14:463-467.

Mezquita, P., Mezquita, C \& Mezquita, J. 1999. Novel transcripts of CA II in mouse and human testis. MHR: Basic science of reproductive medicine, 5 (3): 1 pp: 199-205.

Min Y, Sun T, Niu Z, \& Liu F. 2016. Vitamin C and vitamin E supplementation alleviates oxidative stress induced by dexamethasone and improves fertility of breeder roosters. Anim Reprod Sci., 171:1e6.

Miyake, T \& Pincus, G. 1959. Hormonal influences on the CA concentration in the accessory reproductive tracts of the rat. Endocrinology, 65:64-72.

Morissette, M., Litim, N., \& Di Paolo T. 2017. Chapter 2 Natural Phytoestrogens: A Class of Promising Neuroprotective Agents for Parkinson Disease. In Brahmachari G. Discovery and Development of Neuroprotective Agents from Natural Products. Elsevier Science. p. 32. doi:10.1016/B978-0-12-809593-5.00002-1. ISBN 978-0-12-809769-4.

Motaleb, M., Hossain, M., Alam, M., Abdullah-Al Mamun, M. \& Sultana, M. 2013. Commonly Used Medicinal Herbs and Shrubs by Traditional Herbal Practitioners Glimpses from Thanchi upazila of Bandarban. IUCN, International Union for Conservation of Nature.

Neuman S, Lin T, \& Heste P. 2002. The effect of dietary carnitine on semen traits of White Leghorn roosters. Poult Sci., 81:495e503.

Ommati, M.M., Zamiri, M.J., Akhlaghi, A, Atashi, H, Jafarzadeh, M.R., \& Rezvani, M.R. 2013. Seminal characteristics, sperm fatty acids, and blood biochemical attributes in breeder roosters orally administered with sage (Salvia officinalis) extract. Anim Prod Sci., 53:548e54.

Pandey, A.K. 2010. Anti-staphylococcal activity of a pan-tropical aggressive and obnoxious weed Parihenium histerophorus: an in vitro study. National Academy Science Letters. 30(11-12): 383-386.

Parkkila, S., Kaunisto, K, Kellokumpu, S \& Rajaniemi, H. 1991. A high activity CA isoenzyme (CA II) is present in mammalian spermatozoa. Histochemistry, 95: 477-482.

Pincus, G \& Bialy, G. 1963. CA in steroid-responsive tissues. Recent Prog Horm Res, 19:201-250.

Rengaraj D, \& Hong Y. Effects of dietary vitamin E on fertility functions in poultry species. Int J Mol Sci, 16:9910e21.

Ridderstråle Y, Ekstedt E \& Plöen L. 1985. Localization of CA in testis. Acta Physiol Scand 124 Suppl 542:408.

Roy, M. K., Nakahara K., Na T.V., Trakoontivakorn G., Takenaka M., \& Isobe S. 2007. Baicalein- a flavonoid extracted from a methanolic extract of Oroxylum indicum inhibits proliferation of a cancer cell line in vitro via induction of apoptosis. Pharmazie, 62(2): 149-153. 
Salim, Z. \& Munadi, E. 2017. Info Komoditi Tanaman Obat. Badan Pengkajian dan Pengembangan Perdagangan Kementerian Perdagangan Republik Indonesia

Sankara, S., \&Nair, A.G.R. 1972. Flavonoids of stem bark of Oroxylum indicum. Curr Sci. 41: 62-63.

Tajima, Y, Okamura, N \& Sugita, Y. 1987 The activating effects of bicarbonate on sperm motility and respiration at ejaculation. Biochem Biophys Acta, 924:519-529.

Tenpe C.R., Upaganlawar A., Burle S., \&Yeole Y.G. 2009. In vitro antioxidant and preliminary hepatoprotective activity of Oroxylum indicum (Vent.) leaf extracts. Pharma online, 1: 35-43.

Tepsuwan A., Furihata C., Rojanapo W., \& Matsuhima T. 1992. Genotoxicity and cell proliferative acitivity of a nitro-sated Oroxylum indicum (Vent.) fraction in the pyloric mucosa of rat stomach. Mutat Res., 281(1): 55-61.

Uddin, K.A., Sayeed, A., Rahman I.A.A., Khatun S., Khan G.R.M.A.M., \& Sadik M.G. 2003. Biological activitives of extracts and two flavonoids from Oroxylum indicum Vent. (Bignoniaceae). J Biol Sci., 3(3): 371-375.
Upaganlawar B., \& Tenpe C.R. 2007. In vitro antioxidant activity of leaves of Oroxylum indicum (Vent.). Biomed., 2(3): 300304.

Waldeyer A \& Häusler G. 1959. Histochemical studies of the CA activity of vas deferens and its accessory glands in the Mus Rattus. Acta Biol Germ Med., 2:568-589.

Walker, R. S., P. D. Burns, J. C. Whittier, G. E. Seidel, \& D. D. Zalesky. 2005. Evaluation of gonadotropin releasing hormone and insemination time using the CO-synch protocol in beef cows. Prof. Anim. Sci., 21:190.

Yan R., Cao Y., Chen C., Dai H., Yu S., Wei J., Li H., \& Yang B. 2011. Antioxidant flavonoids from the seed of Oroxylum indicum. Fitoterapia, 82: 841-884.

Zhandi, M., M Ansari, P Roknabadi, A Zare Shahneh \& M Sharafi, 2017. Orally administered Chrysin improves post-thawed sperm quality and fertility of rooster, Reproduction in Domestic Animals, 52, 6, (1004-1010). 